\title{
Synthesis of Ibuprofen Conjugated Molecular Transporter Capable of Enhanced Brain Penetration
}

\author{
Goutam Biswas, ${ }^{1}$ Wanil Kim, ${ }^{2}$ Kyong-Tai Kim, ${ }^{2}$ Junhwi Cho, ${ }^{3}$ \\ Dongjun Jeong, ${ }^{4}$ Keon-Hyoung Song, ${ }^{5}$ and Jungkyun $\mathrm{Im}^{3}$ \\ ${ }^{1}$ India Innovation Research Centre, 465 Patparganj Industrial Area, Delhi 110092, India \\ ${ }^{2}$ Department of Life Science, Division of Molecular and Life Science and Division of Integrative Biosciences and Biotechnology, \\ Pohang University of Science and Technology, Pohang, Republic of Korea \\ ${ }^{3}$ Department of Chemical Engineering, Soonchunhyang University, Asan, Republic of Korea \\ ${ }^{4}$ Department of Pathology, Soonchunhyang University, Asan, Republic of Korea \\ ${ }^{5}$ Department of Pharmaceutical Engineering, Soonchunhyang University, Asan, Republic of Korea
}

Correspondence should be addressed to Jungkyun Im; jkim5279@sch.ac.kr

Received 23 August 2016; Revised 28 November 2016; Accepted 29 November 2016; Published 16 January 2017

Academic Editor: Josefina Pons

Copyright (C) 2017 Goutam Biswas et al. This is an open access article distributed under the Creative Commons Attribution License, which permits unrestricted use, distribution, and reproduction in any medium, provided the original work is properly cited.

Based on the strong evidences between inflammation and neurodegeneration, nonsteroidal anti-inflammatory drugs (NSAIDs), such as ibuprofen, are considered as effective agents to reduce the risk of Alzheimer's and Parkinson's disease. However, the clinical use of NSAIDs in these diseases is limited by low brain distribution. In this study, we had synthesized ibuprofen conjugate which has good brain penetration. S-(+)-Ibuprofen was covalently attached to a molecular transporter having FITC and eight terminal guanidine groups. This conjugate showed good cellular uptake property in live cells. It was also injected into a mouse and the distribution of the compound was examined in each organ. The conjugate was well delivered to mouse brain indicating the conjugate is able to cross the blood-brain barrier. Our novel synthetic ibuprofen conjugate will hopefully deliver other NSAIDs into brain and is therefore applicable to the neurodegenerative diseases treatment or prevention.

\section{Introduction}

Nonsteroidal anti-inflammatory drugs (NSAIDs) are effective for relieving pain and reducing inflammation. These are nonselective inhibitors of two isoforms of cyclooxygenase (COX), cyclooxygenase-1 (COX-1) and cyclooxygenase-2 (COX-2), and thereby inhibit the production of hormone-like lipid compounds such as prostaglandins and thromboxane which cause inflammation, pain, fever, and platelet aggregation $[1,2]$. Approximately 33 million Americans annually use these compounds for the symptomatic relief of headache, osteoarthritis, rheumatoid arthritis, low back pain, and musculoskeletal conditions. Moreover, many epidemiological studies demonstrate that NSAIDs have a neuroprotective effect against neurodegenerative diseases, such as Alzheimer's disease and Parkinson's disease [3-7]. Brain response to cellular stress, injury, and pathology can lead to neuroinflammation which upregulates microglia cells. The aberrantly activated microglia could induce chronic inflammation and cellular damage by producing diverse cytokines and reactive oxygen species (ROS), accelerating neuronal death and resulting in neurodegenerative disease [8-10]. Since NSAIDs can reduce inflammation in brain and allow beneficial effects on preventing or reducing neurodegenerative diseases, along with the principal therapeutic effect (e.g., anti-inflammation) of NSAID, herein we would focus on its neuroprotective effects.

Ibuprofen is a propionic acid derivative among NSAID classes and was the first nonaspirin NSAID to be available over the counter and has become the most commonly used NSAID. Recently, it is reported that long term oral administration of ibuprofen could delay the onset of Alzheimer's, as is found with other NSAIDs [11, 12]. When ibuprofen was fed to transgenic mice models for Alzheimer's, both central nervous system (CNS) inflammation and Alzheimer plaque deposition in the brain were significantly reduced [11]. In 


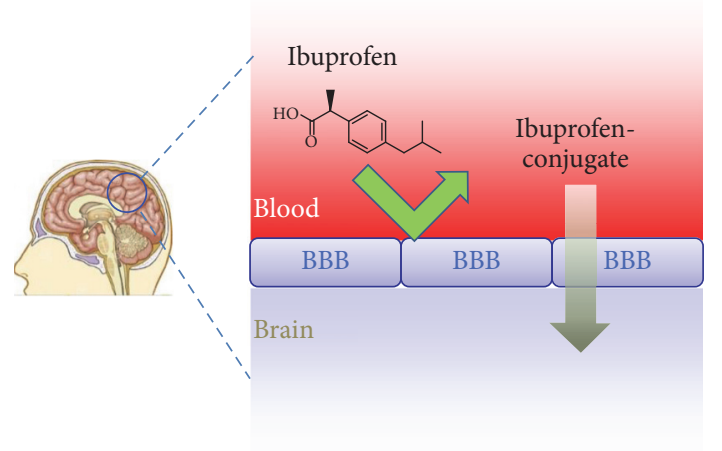

FIgURE 1: The presence of BBB prevents the ibuprofen internalization into the brain. Our objective is to make ibuprofen conjugate pass through the BBB.

clinical research, data from almost 250,000 cases showed those who took NSAID for more than five years were more than $40 \%$ less likely to develop Alzheimer's [12]. The study also revealed that, among the NSAIDs taken by patients, ibuprofen showed the most profound effect. Furthermore, a study suggests taking ibuprofen regularly to be also associated with lowering the risk of the development of Parkinson's disease [13]. The study reported that those taking ibuprofen regularly more than six years showed a 38\% lower risk of developing the disorder than nonusers and other NSAIDs, such as aspirin and paracetamol, did not show any effect to the patients.

However, there are many challenges to be overcome for ibuprofen and other NSAIDs to be used as treatments for neural disorders. First, the presence of blood-brain barrier (BBB) has been reported to significantly limit the brain penetration of NSAIDs (Figure 1) [14-17]. The BBB between cerebral blood and the interstitial fluid of the brain acts as protection from an influx of pathogens as well as small useful molecular drugs like NSAIDs. In addition, ibuprofen is ionized at physiological $\mathrm{pH}$ and circulates as anions, which are extensively bound to plasma proteins by noncovalent associations $[18,19]$. As a consequence, brain penetration of ibuprofen was found to be low in rats, showing the total brain to plasma ratio being less than 0.02 . Therefore, ibuprofen reaching the human brain exists in only a tiny amount and high doses might be required to attain a certain level of drug efficacy toward neural disorders. Also, long term use of ibuprofen can cause a number of side-effects, such as cardiovascular and gastrointestinal risks.

Therefore, to make ibuprofen a more potent drug to prevent or alleviate neurodegenerative diseases even in low doses, delivery of ibuprofen to brain should be effective and ibuprofen must penetrate the $\mathrm{BBB}$ and gain access into the patient's brain.

We have recently developed several types of guanidinerich molecular carriers with high molecular weights and good water solubility that readily cross the $\mathrm{BBB}$ and display efficient distributions in the mouse brain [20, 21]. In particular, the G8 (having eight guanidine groups) molecular carrier based on carbohydrate, such as sorbitol, was found to be very effective in delivering conjugated drugs to mouse brain [22-25]. In the present study, employing the same molecular carrier, we prepared the ibuprofen conjugate and studied its BBB permeability by mouse tissue distribution study.

\section{Experimental}

2.1. Materials and Methods in Synthesis. Analytical TLC was performed on Merck 60 F254 silica gel plate $(0.25 \mathrm{~mm}$ thickness) and visualized under UV light and/or by spraying with a 5\% solution of phosphomolybdic acid (PMA) in ethanol or ninhydrin specific for amino compounds, followed by charring with a heat gun. Column chromatography was performed on Merck 60 silica gel (70-230 or 230-400 mesh) and MPLC on Fluka 100 C8-reversed phase silica gel. NMR spectra were recorded on a Bruker ASPECT 300 instrument operating at $300 \mathrm{MHz}$ for ${ }^{1} \mathrm{H}, 75 \mathrm{MHz}$ for ${ }^{13} \mathrm{C}$. Chemical shifts were reported in parts per million (ppm) relative to tetramethylsilane (TMS) or deuterium oxide $\left(\mathrm{D}_{2} \mathrm{O}\right)$ which were used as internal and external standard for the ${ }^{1} \mathrm{H}$ NMR. Mass spectra were recorded on fast atom bombardment (FAB) conditions. In case of high mass spectral data, MALDITOF were obtained on a Micromass M@DI at the Biomolecular Diversity Core Facility (POSTECH). Analytical HPLC was performed on Agilent 1100-HPLC Chemstation with an analytical column ZORBAX C8-monomeric (BU-300, $5 \mu \mathrm{m}$, $300 \AA, 4.6 \times 250 \mathrm{~mm})$.

\subsection{Characterization of Synthetic Compounds}

(S)-Ethyl-2-(2-(4-isobutylphenyl)propanamido)acetate (1). A solution of $(S)-(+)$-ibuprofen $(140 \mathrm{mg}, 0.68 \mathrm{mmol})$, glycine ethylester hydrochloride (104 mg, $0.75 \mathrm{mmol})$, EDC (195 mg, $1.02 \mathrm{mmol})$, triethylamine $(1.04 \mathrm{ml}, 0.748 \mathrm{mmol})$, and DMAP (42 mg, $0.34 \mathrm{mmol})$ in DMF $(2 \mathrm{ml})$ was stirred at rt under $\mathrm{N}_{2 \text { (g) }}$. After stirring for $24 \mathrm{~h}$, the solution was treated with ethylacetate and washed several times with saturated aq. $\mathrm{NaHCO}_{3}$, water, and brine. The organic phase was dried over $\mathrm{Na}_{2} \mathrm{SO}_{4}$ and concentrated to give the crude product, which was purified by column chromatography on silica gel eluting with 1:5 EtOAc/hexane to afford (1) (199 mg, 99\%) as a colorless liquid.

$R_{f}: 0.54$ (Hexane $:$ EtOAc $\left.=7: 3\right) ;{ }^{1} \mathrm{H}-\mathrm{NMR}(300 \mathrm{MHz}$, $\left.\mathrm{CDCl}_{3}, \mathrm{ppm}\right) \delta 0.99(\mathrm{~d}, J=6.6 \mathrm{~Hz}, 6 \mathrm{H}), 1.23(\mathrm{t}, J=6.9 \mathrm{~Hz}$, $3 \mathrm{H}), 1.51(\mathrm{~d}, J=7.2 \mathrm{~Hz}, 3 \mathrm{H}), 1.84(\mathrm{~m}, 1 \mathrm{H}), 2.44(\mathrm{~d}, J=7.2 \mathrm{~Hz}$, $2 \mathrm{H}), 3.60(\mathrm{q}, J=7.2 \mathrm{~Hz}, 1 \mathrm{H}), 3.94(\mathrm{dd}, J=5.4 \mathrm{~Hz}, J=12.6 \mathrm{~Hz}$, $2 \mathrm{H}), 4.15(\mathrm{q}, J=6.9 \mathrm{~Hz}, 2 \mathrm{H}), 7.11(\mathrm{~d}, J=8.1 \mathrm{~Hz}, 2 \mathrm{H}), 7.22(\mathrm{~d}, J$ $=8.1 \mathrm{~Hz}, 2 \mathrm{H}) ;{ }^{13} \mathrm{C}-\mathrm{NMR}\left(75 \mathrm{MHz}, \mathrm{CDCl}_{3}\right.$, ppm) $\delta 13.9,18.3$, 22.2, 30.0, 41.3, 44.9, 46.2, 61.1, 127.2, 129.4, 138.1, 140.5, 169.7, 174.5; MS (FAB) $[\mathrm{M}+\mathrm{H}]^{+}$calcd for $\mathrm{C}_{17} \mathrm{H}_{25} \mathrm{NO}_{3} \mathrm{~m} / z$ 292.18, found 292.20 .

(S)-2-(2-(4-Isobutylphenyl)propanamido)acetic acid (2). Compound (1) (195 mg, $0.67 \mathrm{mmol}$ ) and lithium hydroxide (16 mg, $0.67 \mathrm{mmol})$ were added to $6 \mathrm{ml}$ solution of THF : $\mathrm{H}_{2} \mathrm{O}(5: 1)$ and stirred at $\mathrm{rt}$ for $36 \mathrm{~h}$. Then the reaction mixture was evaporated in vacuo, extracted with EtOAc, and washed with saturated $1 \mathrm{~N} \mathrm{HCl}$, water, and brine. The organic phase was dried over $\mathrm{Na}_{2} \mathrm{SO}_{4}$ and concentrated to give the crude 
product, which was purified by column chromatography on silica gel eluting with 1:2 EtOAc/hexane to afford (2) (105 mg, $60 \%)$ as a white solid.

$R_{f}: 0.12$ (Hexane: EtOAc $=7: 3$ ); M.p. $87-90^{\circ} \mathrm{C} ;{ }^{1} \mathrm{H}-\mathrm{NMR}$ $\left(300 \mathrm{Mhz}, \mathrm{CDCl}_{3}, \mathrm{ppm}\right) \delta 0.88(\mathrm{~d}, J=6.6 \mathrm{~Hz}, 6 \mathrm{H}), 1.49(\mathrm{~d}, J$ $=7.2 \mathrm{~Hz}, 3 \mathrm{H}), 1.83(\mathrm{~m}, 1 \mathrm{H}), 2.43(\mathrm{~d}, J=7.2 \mathrm{~Hz}, 2 \mathrm{H}), 3.62(\mathrm{q}, J=$ $7.2 \mathrm{~Hz}, 1 \mathrm{H}), 3.94(\mathrm{dd}, J=5.4 \mathrm{~Hz}, J=18.3 \mathrm{~Hz}, 2 \mathrm{H}), 6.35(\mathrm{~m}, 1 \mathrm{H}$, $\mathrm{NH}), 7.09(\mathrm{~d}, J=8.1 \mathrm{~Hz}, 2 \mathrm{H}), 7.18(\mathrm{~d}, J=8.1 \mathrm{~Hz}, 2 \mathrm{H}) ; \mathrm{MS}(\mathrm{FAB})$ $[\mathrm{M}+\mathrm{H}]^{+}$calcd for $\mathrm{C}_{15} \mathrm{H}_{21} \mathrm{NO}_{3} \mathrm{~m} / z$ 264.15, found 264.17.

1-O-(N-Cbz-6-aminohexanoyl)-2,3,4,5-tetra-O-(N-\{bis-[3-(N', $N^{\prime \prime}$-bis-Boc-guanidino)-propyl]\}-6-aminohexanoyl)-6-O-Dsorbitol (4). A column of flash silica gel was packed consecutively in hexane with $1 \%$ triethylamine and then hexane with $1 \%$ TFA; a sea sand layer was placed in between layers. Compound (3) (98 mg, $0.028 \mathrm{mmol}$ ) was dissolved in 1\% TFA containing $\mathrm{CH}_{2} \mathrm{Cl}_{2}$ and sonicated for several seconds. The solution was then loaded on the column chromatography and was eluted with increasing $\mathrm{MeOH}$ in $\mathrm{CH}_{2} \mathrm{Cl}_{2}(15: 1)$ to give compound (4) (66 mg, 73\%) as a colorless foamy solid.

$R_{f}: 0.44\left(\mathrm{CH}_{2} \mathrm{Cl}_{2}: \mathrm{MeOH}=10: 1\right) ;{ }^{1} \mathrm{H}-\mathrm{NMR}(300 \mathrm{MHz}$, $\left.\mathrm{CDCl}_{3}, \mathrm{ppm}\right) \delta 1.22-1.79(\mathrm{~m}, 190 \mathrm{H}), 2.02-2.62(\mathrm{~m}, 32 \mathrm{H}), 3.15-$ $3.48(\mathrm{~m}, 18 \mathrm{H}), 3.68(\mathrm{~m}, 2 \mathrm{H}), 4.31-4.40(\mathrm{~m}, 4 \mathrm{H}), 4.89-5.07$ (m, 2H), 5.08 (s, 2H), 5.10-5.30 (m, 2H), $7.34(\mathrm{~m}, 5 \mathrm{H}), 8.51$ (brs, 8H), 11.48 (brs, $8 \mathrm{H}) ;{ }^{13} \mathrm{C}-\mathrm{NMR}\left(75 \mathrm{MHz}, \mathrm{CDCl}_{3}, \mathrm{ppm}\right.$ ) $\delta 14.1,22.7,24.0,24.3,24.8,25.3,26.3,27.1,28.0,28.1,28.3,28.3$, $28.8,29.3,29.7,29.9,33.9,35.5,38.0,39.0,40.9,49.9,51.3,51.5$, $51.5,53.1,63.6,66.5,79.2,79.7,80.0,80.5,83.0,83.3,83.7,84.5$, 84.9, 85.1, 93.4, 114.5, 118.3, 122.6, 127.2, 127.9, 128.0, 128.5, 128.7, 136.7, 142.1, 143.3, 148.7, 153.0, 153.1, 155.8, 156.1, 156.7, 163.5, $171.8,172.5,172.7,172.8,173.1,181.6,185.0,185.2$.

1-O-(2-Aminoacetoxy-ibuprofen $)-2,3,4,5$-tetra-O-(N-\{bis-[3$\left(N^{\prime}, N^{\prime \prime}\right.$-bis-Boc-guanidino)-propyl]\}-6-aminohexanoyl)-6-O(N-Cbz-6-aminohexanoyl)-D-sorbitol (5). To a solution of (4) $(90 \mathrm{mg}, 0.027 \mathrm{mmol})$ in DMF (2 ml) at rt were added (2) (10.7 mg, $0.041 \mathrm{mmol}$ ), EDC (11 mg, $0.054 \mathrm{mmol}$ ), and DMAP $(2 \mathrm{mg}, 0.016 \mathrm{mmol})$. After stirring for $48 \mathrm{~h}$ under $\mathrm{N}_{2(\mathrm{~g})}$, The solution was concentrated under reduced pressure. The residue was dissolved in EtOAc and washed several times with saturated aq. $\mathrm{NaHCO}_{3}$, water, and brine. The organic phase was dried over $\mathrm{Na}_{2} \mathrm{SO}_{4}$ and concentrated to give the crude product, which was purified by column chromatography on silica gel eluting with $1: 20 \mathrm{MeOH} / \mathrm{CH}_{2} \mathrm{Cl}_{2}$ to afford (5) (50 $\mathrm{mg}, 52 \%$ ) as a white foamy solid.

$R_{f}: 0.46\left(\mathrm{CH}_{2} \mathrm{Cl}_{2}: \mathrm{MeOH}=10: 1\right) ;{ }^{1} \mathrm{H}-\mathrm{NMR}(300 \mathrm{MHz}$, $\left.\mathrm{CDCl}_{3}, \mathrm{ppm}\right) \delta 0.88-0.90(\mathrm{~m}, 6 \mathrm{H}), 1.25-1.69(\mathrm{~m}, 193 \mathrm{H}), 2.32-$ $2.45(\mathrm{~m}, 32 \mathrm{H}), 3.08-3.50(\mathrm{~m}, 18 \mathrm{H}), 3.61-3.71(\mathrm{~m}, 2 \mathrm{H}), 3.97-$ $4.29(\mathrm{~m}, 4 \mathrm{H}), 4.85-5.12(\mathrm{~m}, 4 \mathrm{H}), 5.02(\mathrm{~s}, 2 \mathrm{H}), 5.33(\mathrm{~m}, 1 \mathrm{H})$, 7.09-7.12 (m, 2H), 7.22-7.27 (m, 2H), $7.33(\mathrm{~m}, 5 \mathrm{H}), 8.49-8.57$ $(\mathrm{m}, 8 \mathrm{H}), 11.40(\mathrm{~m}, 8 \mathrm{H}) ;{ }^{13} \mathrm{C}-\mathrm{NMR}\left(75 \mathrm{MHz}, \mathrm{CDCl}_{3}, \mathrm{ppm}\right) \delta$ $14.1,18.6,22.4,22.7,24.0,24.3,24.6,26.3,28.0,28.1,28.3,28.3$, 29.4, 29.7, 30.2, 31.9, 38.0, 39.0, 45.1, 49.9, 53.2, 66.5, 79.2, 79.8, 83.0, 83.7, 118.3, 122.6, 127.2, 127.4, 127.7, 127.9, 128.0, 128.5, 128.7, $129.5,129.7,136.7,138.7,140.5,143.3,153.0,153.1,156.2,156.5$, $156.8,162.9,163.5,170.3,172.6,172.8,174.3,181.6$.

1-O-(2-Aminoacetoxy-ibuprofen $)-2,3,4,5$-tetra-O-(N-\{bis-[3$\left(N^{\prime}, N^{\prime \prime}\right.$-bis-Boc-guanidino)-propyl]\}-6-aminohexanoyl)-6-O-Dsorbitol (6). A solution of (5) ( $45 \mathrm{mg}, 0.013 \mathrm{mmol})$ in a mixed solvent $\left(\mathrm{CH}_{2} \mathrm{Cl}_{2}: \mathrm{MeOH}=1: 9,10 \mathrm{ml}\right)$ was hydrogenated (50 psi) at rt over $10 \% \mathrm{Pd} / \mathrm{C}(25 \mathrm{mg})$. After $12 \mathrm{~h}$, the catalyst was filtered and the filtrate was evaporated to give the amino compound (6) (38 mg, 88\%) as a colorless sticky liquid.

${ }^{1} \mathrm{H}-\mathrm{NMR}\left(300 \mathrm{MHz}, \mathrm{CDCl}_{3}\right.$, ppm) $\delta 0.88-0.90(\mathrm{~m}, 6 \mathrm{H})$, $1.25-1.77(\mathrm{~m}, 193 \mathrm{H}), 2.25-2.45(\mathrm{~m}, 32 \mathrm{H}), 3.09-3.50(\mathrm{~m}, 18 \mathrm{H})$, 3.61-3.71 (m, 2H), 4.01-4.29 (m, 4H), 4.85-5.12 (m, 4H), 5.33 (m, 1H), 7.09-7.12 (m, 2H), 7.22-7.27 (m, 2H), 8.56 (brs, $8 \mathrm{H})$, 11.39 (brs, $8 \mathrm{H}$ ).

1-O-(2-Aminoacetoxy-ibuprofen)-2,3,4,5-tetra-O-(N-\{bis-[3$\left(N^{\prime}, N^{\prime \prime}\right.$-bis-Boc-guanidino)-propyll\}-6-aminohexanoyl)-6-O[6-(fluoresceinyl-5-thioureido)-hexanoyl]-D-sorbitol (7). To a solution of amino compound (6) $(38 \mathrm{mg}, 0.011 \mathrm{mmol})$ in a mixed solvent THF and absolute ethanol $(3 \mathrm{ml}, 1: 2)$ were added fluorescein-5-isothiocyanate $(6.5 \mathrm{mg}, 0.017 \mathrm{mmol})$ and triethylamine $(4.6 \mu \mathrm{l}, 0.033 \mathrm{mmol})$. The reaction mixture was stirred for $36 \mathrm{~h}$ at $\mathrm{rt}$ in dark and then concentrated in vacuo. The crude product was purified on silica gel eluting with 1:20 MeOH/CH $\mathrm{Cl}_{2}$ to afford (7) $(25 \mathrm{mg}, 60 \%)$ as a light greenish-yellow sticky solid.

$R_{f}: 0.42\left(\mathrm{CH}_{2} \mathrm{Cl}_{2}: \mathrm{MeOH}=10: 1\right) ;{ }^{1} \mathrm{H}-\mathrm{NMR}(300 \mathrm{MHz}$, $\left.\mathrm{CDCl}_{3}, \mathrm{ppm}\right) \delta 0.88-0.90(\mathrm{~m}, 6 \mathrm{H}), 1.25-1.85(\mathrm{~m}, 193 \mathrm{H}), 2.31-$ $2.44(\mathrm{~m}, 32 \mathrm{H}), 3.09-3.48(\mathrm{~m}, 18 \mathrm{H}), 3.66(\mathrm{~m}, 2 \mathrm{H}), \delta 4.15-4.29$ $(\mathrm{m}, 4 \mathrm{H}), 4.88-5.07(\mathrm{~m}, 4 \mathrm{H}), 5.34(\mathrm{~m}, 1 \mathrm{H}), 6.51-7.32(\mathrm{~m}, 11 \mathrm{H})$, $7.73(\mathrm{~m}, 1 \mathrm{H}), 8.04(\mathrm{~m}, 1 \mathrm{H}), 8.57$ (brs, $8 \mathrm{H}), 11.39$ (brs, $8 \mathrm{H})$.

1-O-(2-Aminoacetoxy-ibuprofen)-2,3,4,5-tetra-O-[N-\{bis-(3guanidinopropyl)\}-6-aminohexanoyl]-6-O-[6-(fluoresceinyl5-thioureido)-hexanoyl]-D-sorbitol. $8 \mathrm{HCl}$ (8). To a solution of (7) $(20 \mathrm{mg}, 0.005 \mathrm{mmol})$ in EtOAc $(1 \mathrm{ml})$ at $\mathrm{rt}$ was added the $\mathrm{HCl}_{(\mathrm{g})}$ saturated solution of EtOAc $(5 \mathrm{ml})$. After stirring for $24 \mathrm{~h}$, the solution was concentrated, and the residue was washed with a mixture of diethyl ether and $\mathrm{MeOH}(20: 1)$ to remove less polar impurities. The residue was dried and purified sequentially by MPLC on reverse phase C- 8 silica gel $\left(\mathrm{H}_{2} \mathrm{O} / \mathrm{CH}_{3} \mathrm{CN}=1: 1\right.$ to $\left.1: 2\right)$ and RP-HPLC (GRACEVYDAC, $\mathrm{C} 18,2.0 \mathrm{ml} \mathrm{min}^{-1}, 10 \%$ to $60 \% \mathrm{CH}_{3} \mathrm{CN}$ in $\mathrm{H}_{2} \mathrm{O}, 220 \mathrm{~nm}$ ). The purified product was lyophilized to give (8) $(7.6 \mathrm{mg}, 58 \%)$ as a light greenish-yellow sticky solid ( $\mathrm{HCl}$ salt).

Analytical HPLC (ZORBAX SB-C8): $t_{R}=2.1 \mathrm{~min}$ (flow rate: $1 \mathrm{~cm}^{3} \mathrm{~min}^{-1}$; UV $=220 \mathrm{~nm}$; isocratic $\mathrm{CH}_{3} \mathrm{CN}: \mathrm{H}_{2} \mathrm{O}$ $=30: 70)$, purity 99+\%; UV $\left(\mathrm{H}_{2} \mathrm{O}\right): \lambda_{\max } 492 \mathrm{~nm}, \varepsilon=$ $18,333 \mathrm{~cm}^{-1} \mathrm{M}^{-1}$ ); ${ }^{1} \mathrm{H}-\mathrm{NMR}(300 \mathrm{MHz}, \mathrm{MeOD}, \mathrm{ppm}) \delta 0.89-$ $0.91(\mathrm{~m}, 6 \mathrm{H}), 1.01-1.80(\mathrm{~m}, 45 \mathrm{H}), 2.00-2.09(\mathrm{~m}, 16 \mathrm{H}), 2.38-$ $2.43(\mathrm{~m}, 16 \mathrm{H}), 3.29-3.32(\mathrm{~m}, 16 \mathrm{H}$, partially overlapped with MeOD peak), 3.48-3.88 (m, 6H), 4.03-4.55 (m, 9H), 5.00$5.41(\mathrm{~m}, 2 \mathrm{H}), 6.66-6.78(\mathrm{~m}, 6 \mathrm{H}), 7.09-7.34(\mathrm{~m}, 4 \mathrm{H}), 7.70(\mathrm{~m}$, $1 \mathrm{H}), 7.80(\mathrm{~m}, 1 \mathrm{H}), 8.06(\mathrm{~m}, 1 \mathrm{H})$; MALDI-TOF-MS $[\mathrm{M}+\mathrm{Na}]^{+}$ calcd for $\mathrm{C}_{104} \mathrm{H}_{171} \mathrm{~N}_{31} \mathrm{O}_{18} \mathrm{SNa} m / z$ 2198.30, found 2198.96.

Fluoresceinyl (S)-2-(2-(4-Isobutylphenyl)propanamido)-acetate (9). A solution of $(S)-(+)$-ibuprofen (70 $\mathrm{mg}, 0.34 \mathrm{mmol})$, fluorescein amine $(129 \mathrm{mg}, 0.37 \mathrm{mmol}), \mathrm{EDC}(97 \mathrm{mg}$, $0.51 \mathrm{mmol})$, and DMAP (21 mg, $0.17 \mathrm{mmol})$ in DMF (2 ml) was stirred at $\mathrm{rt}$ under $\mathrm{N}_{2(\mathrm{~g})}$. After $24 \mathrm{~h}$, the solution was treated with EtOAc and washed several times with saturated aq. $\mathrm{NaHCO}_{3}$, water, and brine. The organic phase was dried and concentrated to give the crude product, which was 
purified by column chromatography on silica gel eluting with 1:20 MeOH/ $\mathrm{CH}_{2} \mathrm{Cl}_{2}$ to afford (9) (140 mg, 77\%) as a yellowish sticky liquid.

$R_{f}: 0.54\left(\mathrm{CH}_{2} \mathrm{Cl}_{2}: \mathrm{MeOH}=10: 1\right) ;{ }^{1} \mathrm{H}-\mathrm{NMR}(300 \mathrm{MHz}$, $\left.\mathrm{CDCl}_{3}, \mathrm{ppm}\right) \delta 0.90(\mathrm{~d}, J=6.6 \mathrm{~Hz}, 6 \mathrm{H}), 1.59(\mathrm{~d}, J=7.2 \mathrm{~Hz}$, $3 \mathrm{H}), 1.85(\mathrm{~m}, 1 \mathrm{H}), 2.46(\mathrm{~d}, J=7.2 \mathrm{~Hz}, 2 \mathrm{H}), 6.54-6.72(\mathrm{~m}$, $4 \mathrm{H}), 6.78-6.95(\mathrm{~m}, 4 \mathrm{H}), 7.11(\mathrm{~m}, 3 \mathrm{H}), 7.28(\mathrm{~m}, 2 \mathrm{H}) ;{ }^{13} \mathrm{C}-\mathrm{NMR}$ $\left(75 \mathrm{MHz}, \mathrm{CDCl}_{3}, \mathrm{ppm}\right) \delta 18.7,22.7,30.5,31.8,36.9,45.3,45.5$, 103.2, 108.7, 110.3, 110.3, 110.8, 113.0, 117.2, 117.2, 117.7, 122.7, 124.9, $127.5,128.3,129.3,129.4,129.9,137.2,141.2,142.9,148.7,152.2$, $152.3,152.6,159.5,163.1,170.3,173.2$; MS (FAB) $[\mathrm{M}+\mathrm{H}]^{+}$calcd for $\mathrm{C}_{33} \mathrm{H}_{29} \mathrm{NO}_{6} \mathrm{~m} / z$ 535.20, found 535.19.

\subsection{Biological Assays}

2.3.1. Materials. High glucose Dulbecco's modified Eagle's medium (DMEM), Dulbecco's phosphate buffered saline (PBS, pH 7.4), fetal bovine serum (FBS), and trypsin/EDTA were obtained from Invitrogen. Milli-Q purified water $(18.2 \mathrm{M} \Omega$ ) was used to prepare all of the solutions.

2.3.2. Cell Culture. HeLa cells were incubated at $37^{\circ} \mathrm{C}$ in a humidified $5 \% \mathrm{CO}_{2}$ containing air environment in DMEM and $10 \%(\mathrm{v} / \mathrm{v})$ FBS with penicillin. The subculture was performed every 2-3 days until the cells were grown to subconfluence.

2.3.3. Cellular Uptake Experiment. HeLa cells $\left(1 \times 10^{5}\right.$ cells per well) were seeded into a $35 \mathrm{~mm}$ cover glass bottomed dish (SPL Ltd., Republic of Korea) and incubated for $24 \mathrm{~h}$. After removing the media, HeLa cells were washed with cold PBS $(\times 1)$. The cells were incubated for $30 \mathrm{~min}$ at $37^{\circ} \mathrm{C}$ in $3 \mathrm{ml}$ of DMEM containing $10 \mu \mathrm{M}$ of compound (8) or (9). After incubation, the cell media were removed and HeLa cells were washed five times with cold PBS, replaced with cold PBS, and then observed directly on the cover glass bottom dish. Confocal laser scanning microscope was performed by using an Olympus Fluoview FV1000 equipped with an NA 1.30, 40x, planApo, oil immersion lens. Fluorescence of FITC was analyzed and collected using the excitation bands at $488 \mathrm{~nm}$ and emission bands from 500 to $530 \mathrm{~nm}$. All the experiment was performed in triplicate.

2.3.4. Mouse Tissue Biodistribution. Compound (8) or (9) $\left(94.6 \mathrm{mg} \mathrm{kg}^{-1}\right)$ was dissolved in sterile distilled water $(500 \mu \mathrm{L})$ and each solution was injected intraperitoneally (ip) into eight-week-old mice (C57BL/6, $22 \mathrm{~g}$ ). After $20 \mathrm{~min}$, the administered mice were perfused with paraformaldehyde (4\%) in PBS ( $\mathrm{pH} 7.4$ ), and the major organs (brain, heart, lung, kidney, spleen, and liver) were incubated overnight in a solution of sucrose $(0.5 \mathrm{M})$ in PBS. Placed in cryoprotectant, they were cut into $15 \mu \mathrm{m}$ sections with a cryostat and transferred to coated glass slides. After drying, each section was washed with PBS, treated with Triton X-100 (0.3\%) for $15 \mathrm{~min}$ at $\mathrm{rt}$, and then analyzed with an Axioplan2 fluorescence imaging microscope. As a control, triple distilled water $(500 \mu \mathrm{L})$ was also injected into the mouse and treated in the same process. Green fluorescence from FITC labeled compounds in each tissue was compared with autofluorescence from the control. All mouse experiments were performed in the POSTECH animal facility in compliance with the relevant laws and institutional guidelines.

2.3.5. Plasma Stability Test. A homogenous solution of (8) in distilled water $\left(500 \mu \mathrm{g} \mathrm{ml}^{-1}\right)$ was prepared for the determination of plasma stability. Aliquots were withdrawn and added into plasma (from human, Sigma, USA), resulting in a final concentration of $50 \mu \mathrm{g} \mathrm{ml}^{-1}$, which was vortexed and incubated at $37^{\circ} \mathrm{C}$ for predetermined times $(0,3,6,9,12,15,18$, 21 , and $24 \mathrm{~h})$. Then aliquots of plasma solution $(200 \mu \mathrm{l})$ were withdrawn to be mixed with $1 \mathrm{ml} \mathrm{MeOH}$ to prevent further hydrolysis of (8). To the solution was added biotin (internal standard) in distilled water $\left(100 \mu \mathrm{l}, 5 \mu \mathrm{g} \mathrm{ml}^{-1}\right)$ followed by centrifugation at $2000 \mathrm{rpm}$ for $10 \mathrm{~min}$. The supernatant was collected and dried under air flow. The residue was dissolved in distilled water $(2 \mathrm{ml})$ and centrifuged at $2000 \mathrm{rpm}$ for $10 \mathrm{~min}$. The obtained supernatant was analyzed using HPLC by the following method.

2.3.6. HPLC Analysis. As described earlier, a clear supernatant was obtained, and $10 \mu \mathrm{l}$ was injected into HPLC system. The UV detector was operated at $260 \mathrm{~nm}$, and the flow rate used was $1.0 \mathrm{ml} \mathrm{min}^{-1}$ for $10-15 \mathrm{~min}$ running time. The isocratic mobile phase system was composed of $\mathrm{MeOH} / \mathrm{H}_{2} \mathrm{O}(30 / 70)$, and the column oven was maintained at $37^{\circ} \mathrm{C}$ with an analytical C18-column (Agilent, ZORBAX, $4.6 \times$ $250 \mathrm{~mm}, 5 \mu \mathrm{m})$. At each interval, HPLC chromatograms were obtained and the remained percentage of (8) was calculated by subtracting the released ibuprofen concentration, based on area under curve, from the sum of initial concentration of (8) and internal standard.

\section{Results and Discussion}

3.1. Synthesis of Ibuprofen Conjugate. Since the $S-(+)$ enantiomer of ibuprofen (dexibuprofen) is more active in inhibiting the COX enzymes, the $S-(+)$ isomer was used as a model drug of NSAID. Attempting to increase the efficiency of the coupling of ibuprofen into the sterically crowded scaffold (sorbitol), we synthesized an ibuprofen derivative using glycine as a spacer (Scheme 1). $S$-(+)-Ibuprofen was first coupled with ethylglycinate to form compound (1) which was further treated with lithium hydroxide to give the compound (2) in accordance with the reported procedure [26]. The acid (2) was used as a precursor of ibuprofen conjugate.

From our previous study, we had observed that the branched side chains with bis-guanidine moiety at the terminal and five-carbon units in the $\omega$-amino acid chain give better efficiency toward cell penetration than other versions of derivatives [22]. Therefore, we synthesized the ibuprofen attached sorbitol derivative with five-carbon attached side chains (Scheme 2). To synthesize compound (3), we started from the commercially available $\mathrm{D}$-glucose. Following several steps in the reported procedure [22], D-glucose was reduced to acylated sorbitol, which was consecutively coupled with Cbz-protected aminocaproic acid to form compound (3). To 


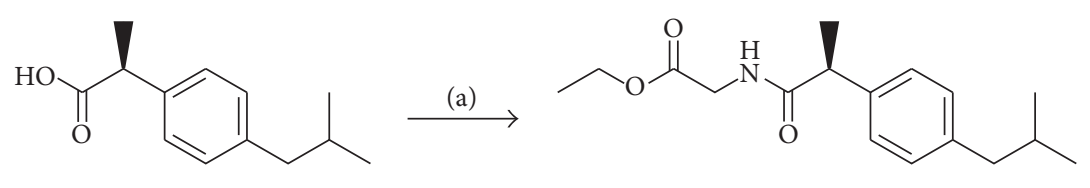

(S)-Ibuprofen

(1)

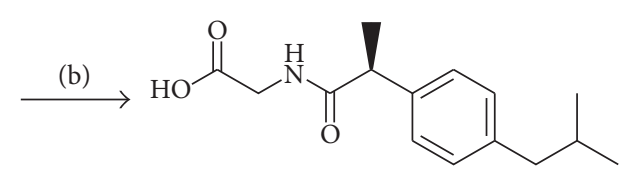

(2)

Scheme 1: (a) Glycine ethylester-HCl, EDC, DMAP, DMF, and Et ${ }_{3} \mathrm{~N}, \mathrm{rt}, 24$ h, 99\%; (b) LiOH and THF-H ${ }_{2} \mathrm{O}(5: 1), \mathrm{rt}, 36$ h, $60 \%$.

remove the trityl group selectively in (3) in the presence of eight Boc groups, gradients of $\mathrm{CH}_{2} \mathrm{Cl}_{2} / \mathrm{MeOH}$ mixture were eluted through a flash $\mathrm{SiO}_{2}$ column packed in hexane containing $1 \%$ TFA at the top and hexane containing $1 \% \mathrm{Et}_{3} \mathrm{~N}$ on the bottom [27]. As a result, compound (4) was obtained in $73 \%$ yield after column chromatography. The hydroxyl group of (4) was coupled with the ibuprofen derivative (2) in the presence of 1-ethyl-3-(3-dimethylaminopropyl)carbodiimide (EDC) and 4-dimethylaminopyridine (DMAP) in DMF to afford the conjugate (5) in moderate yield. The conjugation was covalently formed via an ester bond, which can be easily hydrolyzed to release ibuprofen after reaching the target. Deprotection of $N-\mathrm{Cbz}$ group in the compound (5) was performed using $10 \% \mathrm{Pd} / \mathrm{C}$ and hydrogen gas under $50 \mathrm{psi}$ to give the amino compound (6), which did not require further purification. In order to attach a fluorescent probe, the compound (6) was treated with fluorescein-5-isothiocyanate (FITC) and $\mathrm{Et}_{3} \mathrm{~N}$ in a mixed solvent $\mathrm{THF} / \mathrm{ethanol}$ to give the compound ( 7 ) in moderate yield. Finally, the compound (7) was treated with ethylacetate saturated with $\mathrm{HCl}$ (gas) to remove all the Boc groups of the guanidine moieties to yield compound (8) as hydrochloride salts. The resulting salt (8) was purified by medium pressure liquid chromatography (MPLC) using a reverse-phase (C8) column. In order to compare the delivery efficiency between the compound (8) and the blank compound (i.e., without sorbitol-based molecular transporter), we had synthesized the compound (9) by EDC coupling strategy at room temperature (Scheme 3). Then (9) was further purified by column chromatography on silica gel.

3.2. Cellular Uptake Study of the Ibuprofen Conjugate. In order to check whether the synthetic conjugate (8) can cross the cell membrane and translocate itself inside cells, we investigated its intracellular delivery properties by means of confocal microscope (Olympus Fluoview FV1000, NA 1.30, $40 \mathrm{x})$. The conjugate $(8)(10 \mu \mathrm{M}$ in $\mathrm{PBS})$ was added to the media of live HeLa cells and was incubated together at $37^{\circ} \mathrm{C}$ for $30 \mathrm{~min}$. Then the cells were washed with cold PBS twice and the cellular internalization of the compound and its localization could be examined by the fluorescence of the labeled fluorescein. Figure 2 shows strong green fluorescence appearing mainly in the cytoplasm, and this indicates (8) can cross the cellular membrane and diffuse efficiently in the cytoplasm. However, unlike the ibuprofen conjugate, where ibuprofen conjugated only with FITC (9) was incubated in HeLa cells in the same manner, no fluorescence was observed inside the cells. This result confirms the guanidine moieties in the conjugate structure are completely essential in delivering ibuprofen into cells. Although the exact mechanism of cellular uptake mediated by guanidine is very complicated and sometimes remains controversial, according to recent publications it is assumed that, at the initial stage of cell uptake, a strong association takes place between the cationic guanidine and anionic cell membrane constituents such as sulfate, carboxylate, and phosphate groups [28, 29].

3.3. Mouse Tissue Distribution Experiment. The possibility of $\mathrm{BBB}$ penetration of the conjugate (8) was tested by studying the tissue distribution in mice. The conjugate $(8)(\mathrm{HCl}$ salt, $94.4 \mathrm{mg} \mathrm{kg}^{-1}$ ) was dissolved in sterile distilled water and the solution was injected intraperitoneally into an 8-weekold mouse (C57BL/6). After $20 \mathrm{~min}$, the injected mouse was transcardially perfused with paraformaldehyde in phosphate buffered saline solution ( $\mathrm{pH} 7.4$ ). The major organs such as brain, heart, lung, kidney, spleen, and liver were incubated overnight in a solution of sucrose $(0.5 \mathrm{M})$ in PBS. Placed in cryoprotectant, the tissues were cut into $15 \mu \mathrm{m}$ sections with a cryostat and transferred to coated glass slides. After drying, sections were treated with Triton X-100 for $15 \mathrm{~min}$ and then analyzed with fluorescence microscope (Figure 3). As a control study, only PBS was injected to another mouse. In the previous study, the sorbitol G8 transporter showed preferred distribution patterns to heart and brain than to other tissues [22]. Conjugate (8) shows preferred locations to be in the brain and the kidney, while much less distributions were observed in the spleen and the liver and none in the heart and the lung. This shows the conjugate can readily cross the $\mathrm{BBB}$ and penetrate into the mouse brain. Similarly, (9) was used for the experiment with the same procedure but showed no distribution in the brain. We presume that the guanidinerich region of (8) forms noncovalent bonds with brain cell surface units through charge pairing and hydrogen bonding. After this interaction, (8) might cross the BBB by endocytosis [28, 30]. 


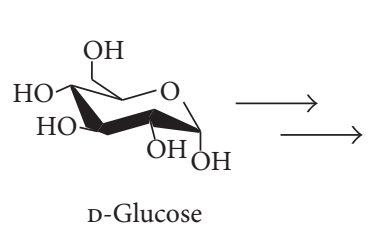

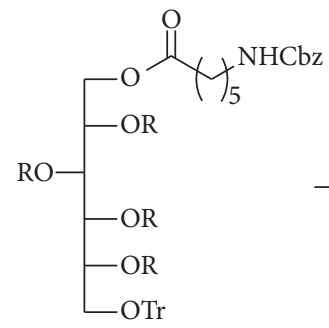

(3)

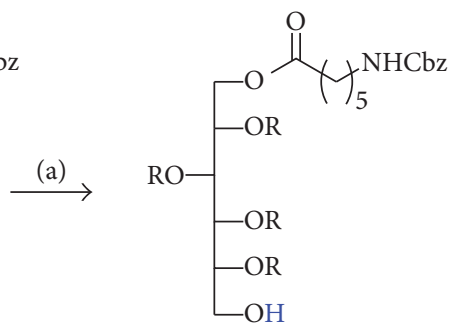

(4)

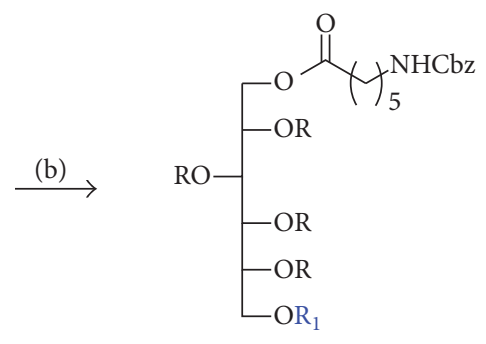

(5)<smiles>[R10]CC([R])C([R])C([R])C([R])C([R])COC(=O)C(C)(C)NC(C)C</smiles>

(7)

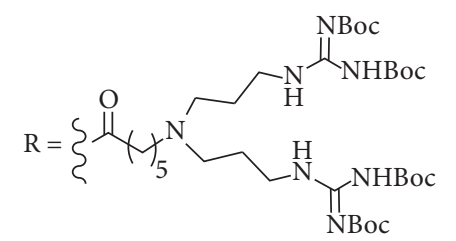

$\stackrel{(\mathrm{e})}{\longrightarrow}$

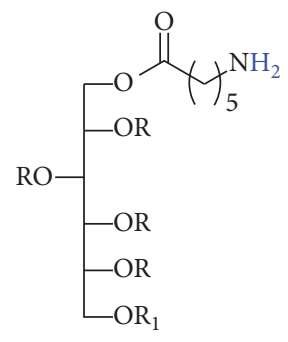

(6)

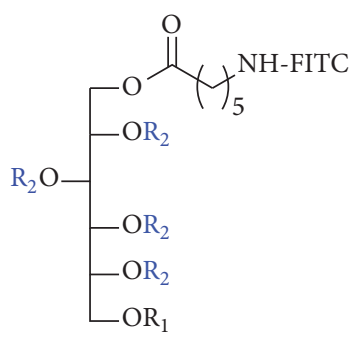

(8)<smiles>[R][SH][SH](C)(=O)C(=O)CNC(=O)[C@H](C)c1ccc(CC(C)C)cc1</smiles><smiles>[R5]SC(=O)C(C)(C)N(CCCCNC(=N)NCCl)CCCNC(N)=NCCl</smiles>

SCHeme 2: (a) $\mathrm{SiO}_{2}$ with hexane-1\% TFA and hexane-1\% $\mathrm{Et}_{3} \mathrm{~N}, 73 \%$; (b) (2), EDC, DMAP, and DMF, rt, $48 \mathrm{~h}, 52 \%$; (c) $10 \% \mathrm{Pd} / \mathrm{C}, \mathrm{H}_{2(\mathrm{~g})}(50 \mathrm{psi})$, and $\mathrm{MeOH}-\mathrm{CH}_{2} \mathrm{Cl}_{2}(9: 1)$, rt, 12 h, 88\%; (d) FITC-I, Et ${ }_{3} \mathrm{~N}$, THF, and EtOH, rt, 36 h, 60\%; (e) $\mathrm{HCl}_{(\mathrm{g})}$ in EtOAc, rt, 24 h, $58 \%$.

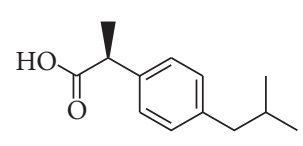

(S)-Ibuprofen $\stackrel{(a)}{\longrightarrow}$<smiles>CC(C)Cc1ccc([C@H](C)C(=O)Nc2ccc3c(c2)C(=O)OC32c3ccc(O)cc3Oc3cc(O)ccc32)cc1</smiles>

(9)

Scheme 3: (a) Aminofluorescein, EDC, DMAP, and DMF, rt, 24 h, 77\%. 


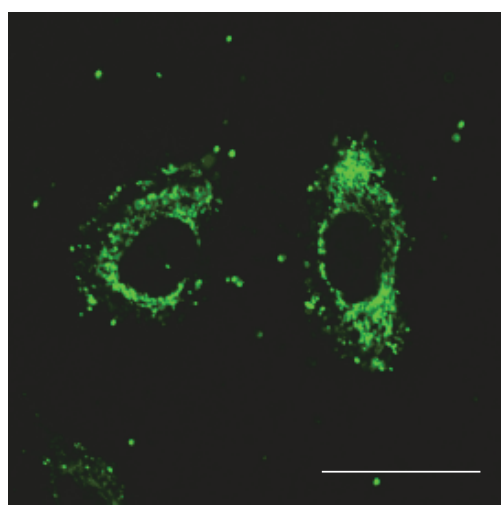

(a)

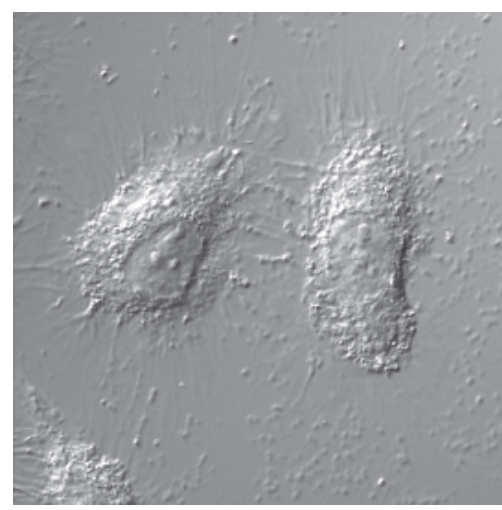

(b)

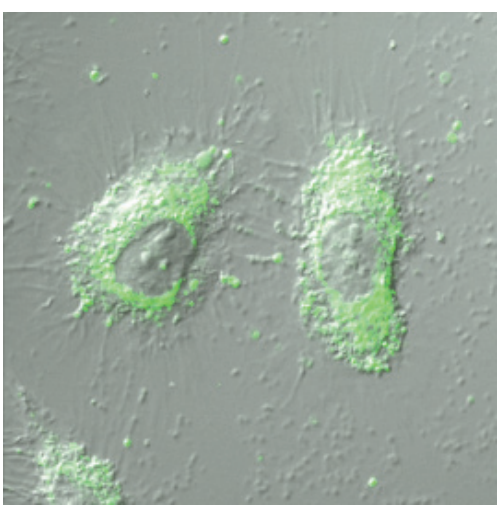

(c)

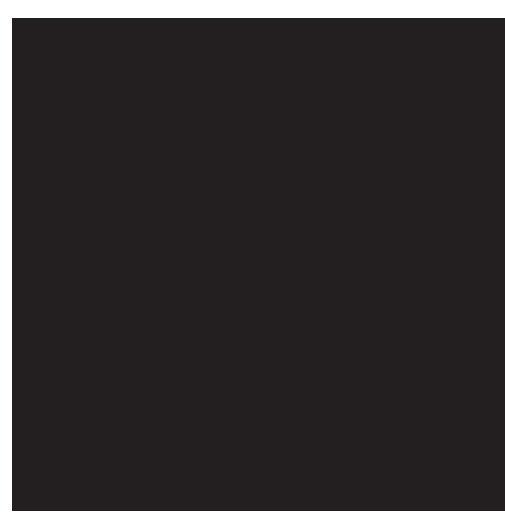

(d)

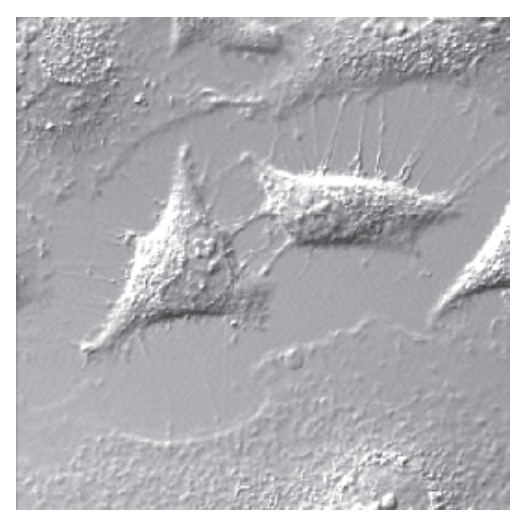

(e)

FIGURE 2: Cellular uptake of (8) and (9) in live HeLa cells. (a) fluorescence image, (b) DIC (differential interference contrast) image, (c) merge image of (a) and (b) from (8) (ibuprofen conjugate) treated cells, (d) fluorescence image, and (e) DIC image from (9) (control) treated cells. Scale bar: $20 \mu \mathrm{m}$.

3.4. In Vitro Plasma Stability Test. To determine the stability of the ibuprofen conjugate, $(\mathbf{8})$ was incubated in the presence of human plasma. Initially, ibuprofen, biotin as internal standard, blank plasma, and (8) were analyzed, respectively, by HPLC at $260 \mathrm{~nm}$ to determine each retention time (min): ibuprofen: 3.9, biotin: 3.1, blank plasma: 4.0 and 5.2, and (8): 7.8 .

Compound (8) was dissolved in distilled water $(500 \mu \mathrm{g}$ $\mathrm{ml}^{-1}$ ), and then aliquots were mixed with plasma to be a concentration of $20 \mu \mathrm{g} \mathrm{ml}^{-1}$. During incubating solution at $37^{\circ} \mathrm{C}$, aliquots $(200 \mu \mathrm{l})$ were withdrawn periodically and mixed with $\mathrm{MeOH}(1 \mathrm{ml})$ and biotin $\left(100 \mu \mathrm{l}, 5 \mu \mathrm{g} \mathrm{ml}^{-1}\right)$ as an internal standard. After centrifugation, the supernatant was collected and $10 \mu \mathrm{l}$ of the solution was injected for RP-HPLC equipped with a C18-analytical column. Samples detecting at $260 \mathrm{~nm}$ showed a slight shift of retention time of each species, and particularly the released ibuprofen was identified by the peak with retention time at $3.96 \mathrm{~min}$ (Figure 4(a)). After $3 \mathrm{~h}$ incubation, compound (8) underwent hydrolysis around 5\% with respect to the initial time $(0 \mathrm{~h})$. With the increase of time, however, the remaining percentage decreased slowly $\sim 8 \%$ in next $21 \mathrm{~h}$ incubation time (Figure $4(\mathrm{~b})$ ). This indicates (8) has sufficient stability and long half life time in plasma, and the compound could gain higher possibility to reach the BBB.

\section{Conclusions}

In conclusion, ibuprofen conjugate (8) was prepared using a sorbitol-based G8 molecular carrier and showed good distribution toward mouse brain. Although there is no cure or protecting agent for neurodegenerative disease yet, NSAIDs are being reported to give beneficial neuroprotection effects. To deliver a drug into brain in optimal dose and to minimize side effects, an efficient and specific delivery system overcoming the $\mathrm{BBB}$ is highly required. We have succeeded in delivering ibuprofen conjugate to mouse brain, and our prodrug methodology is applicable to virtually all other NSAIDs, such as flurbiprofen. Further studies are in progress to demonstrate the delivery of other popular NSAIDs to the brain and the central nervous system.

\section{Competing Interests}

The authors declare that they have no competing interests. 


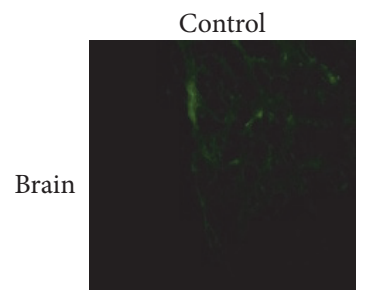

(a)

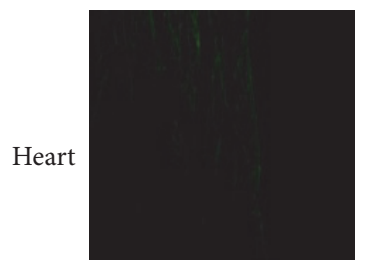

(d)

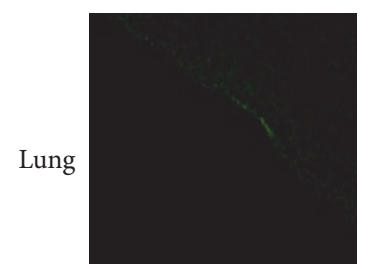

(g)

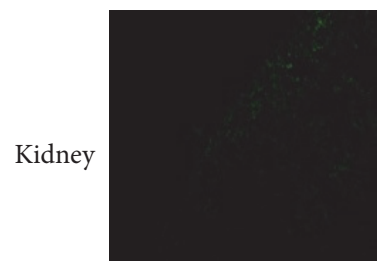

(j)

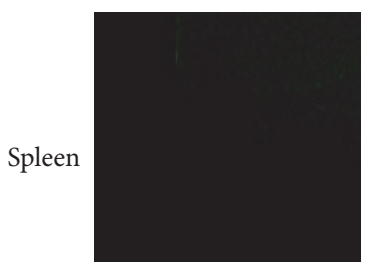

(m)

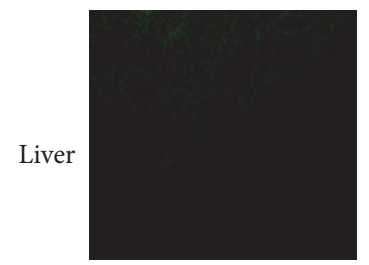

(p)

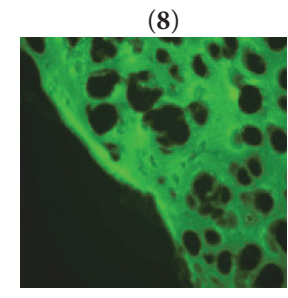

(b)

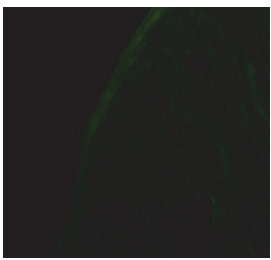

(e)

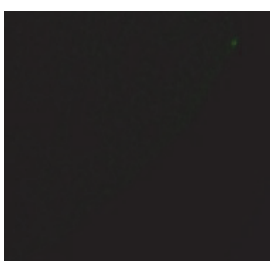

(h)

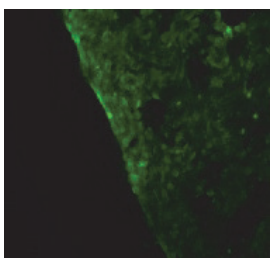

(k)

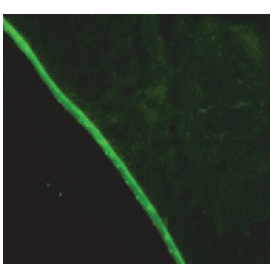

(n)

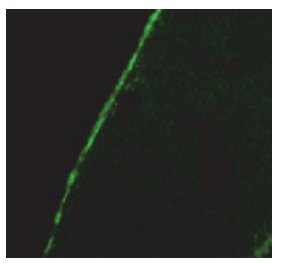

(q)

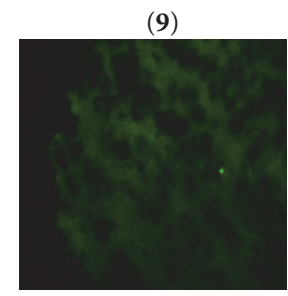

(c)

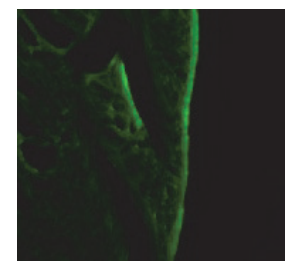

(f)

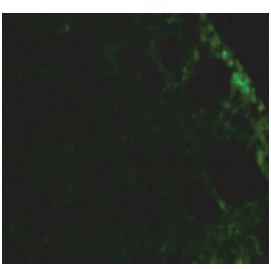

(i)

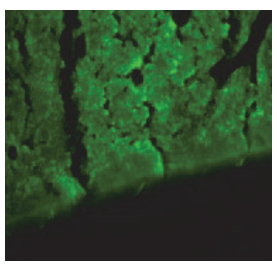

(1)

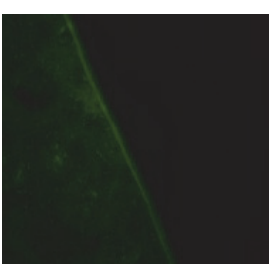

(o)

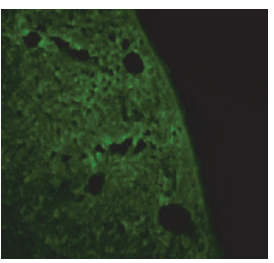

(r)

FIGURE 3: Distribution tests in mouse tissues (left column: control, middle: (8), and right: (9)). Fluorescence micrographs of ((a)-(c)) brain, ((d)-(f)) heart, ((g)-(i)) lung, ((j)-(l)) kidney, ((m)-(o)) spleen, and ((p)-(r)) liver tissue sections, isolated from mice 20 min after ip injection. Exposure times (ms); brain: 5000, heart: 1000, lung: 5000, kidney: 2000, spleen: 2000, and liver: 2000. $\lambda_{\max }=488 \mathrm{~nm}$ (green fluorescence from FITC).

\section{Acknowledgments}

The authors would like to thank Dr. Sung-Kee Chung (honorary professor at Pohang University of Science and Technology) for his kind advice and interest. This research was supported by Basic Science Research Program through the National Research Foundation of Korea (NRF) funded by the Ministry of Science, ICT \& Future Planning (NRF2015R1C1A1A01054657) and partly supported by the Industry Technology R\&D Program of MOTIE/KEIT [10051080, 


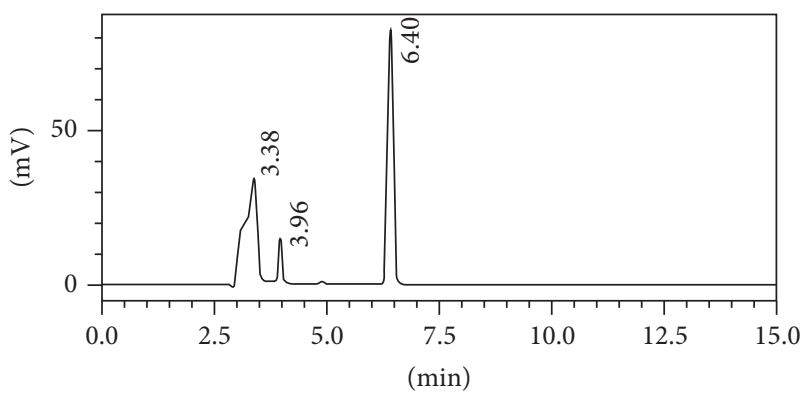

(a)

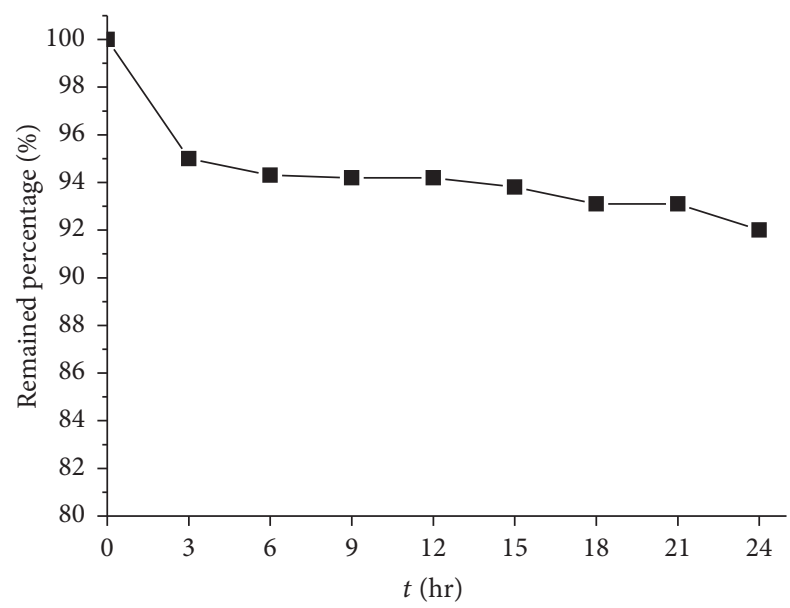

(b)

FIGURE 4: (a) HPLC chromatogram of biotin (internal standard) and (8) in plasma after $3 \mathrm{~h}$ incubation time; retention time of biotin and plasma: $3.38 \mathrm{~min}$, ibuprofen: $3.96 \mathrm{~min}$, and (8): $6.40 \mathrm{~min}$ and (b) the remained percentage of $(8)$ in plasma over incubation time.

development of mechanical UI device core technology for small and medium-sized flexible display]. This work was also supported by the Soonchunhyang University Research Fund.

\section{References}

[1] J. A. Mitchell, P. Akarasereenont, C. Thiemermann, R. J. Flower, and J. R. Vane, "Selectivity of nonsteroidal antiinflammatory drugs as inhibitors of constitutive and inducible cyclooxygenase," Proceedings of the National Academy of Sciences of the United States of America, vol. 90, no. 24, pp. 11693-11697, 1993.

[2] R. J. Flower, "The development of COX2 inhibitors," Nature Reviews Drug Discovery, vol. 2, no. 3, pp. 179-191, 2003.

[3] A. H. Moore, M. J. Bigbee, G. E. Boynton et al., "Non-steroidal anti-inflammatory drugs in Alzheimer's disease and Parkinson's disease: reconsidering the role of neuroinflammation," Pharmaceuticals, vol. 3, no. 6, pp. 1812-1841, 2010.

[4] J. L. Eriksen, S. A. Sagi, T. E. Smith et al., "NSAIDs and enantiomers of flurbiprofen target $\gamma$-secretase and lower A $\beta 42$ in vivo," The Journal of Clinical Investigation, vol. 112, no. 3, pp. 440-449, 2003.

[5] A. Lleó, O. Berezovska, L. Herl et al., "Nonsteroidal antiinflammatory drugs lower $\mathrm{A} \beta 42$ and change presenilin 1 conformation," Nature Medicine, vol. 10, no. 10, pp. 1065-1066, 2004.
[6] M. H. DeLegge and A. Smoke, "Neurodegeneration and inflammation," Nutrition in Clinical Practice, vol. 23, no. 1, pp. 35-41, 2008.

[7] H. Chen, S. M. Zhang, M. A. Hernán et al., "Nonsteroidal antiinflammatory drugs and the risk of Parkinson disease," Archives of Neurology, vol. 60, no. 8, pp. 1059-1064, 2003.

[8] F. L. Heppner, R. M. Ransohoff, and B. Becher, "Immune attack: the role of inflammation in Alzheimer disease," Nature Reviews Neuroscience, vol. 16, no. 6, pp. 358-372, 2015.

[9] T. Wyss-Coray and L. Mucke, "Ibuprofen, inflammation and Alzheimer disease,” Nature Medicine, vol. 6, no. 9, pp. 973-974, 2000.

[10] E. E. Tuppo and H. R. Arias, "The role of inflammation in Alzheimer's disease," The International Journal of Biochemistry \& Cell Biology, vol. 37, no. 2, pp. 289-305, 2005.

[11] G. P. Lim, F. Yang, T. Chu et al., "Ibuprofen suppresses plaque pathology and inflammation in a mouse model for Alzheimer's disease," The Journal of Neuroscience, vol. 20, no. 15, pp. 5709$5714,2000$.

[12] S. C. Vlad, D. R. Miller, N. W. Kowall, and D. T. Felson, "Protective effects of NSAIDs on the development of Alzheimer disease," Neurology, vol. 70, no. 19, pp. 1672-1677, 2008.

[13] X. Gao, H. Chen, M. A. Schwarzschild, and A. Ascherio, "Use of ibuprofen and risk of Parkinson disease," Neurology, vol. 76, no. 10, pp. 863-869, 2011.

[14] Z. Xuan, L. Xing, G. Tao, S. Xun, and Z.-R. Zhang, "In vitro and in vivo investigation of dexibuprofen derivatives for CNS delivery," Acta Pharmacologica Sinica, vol. 33, no. 2, pp. 279288, 2012.

[15] Y. Deguchi, H. Hayashi, S. Fujii et al., "Improved brain delivery of a nonsteroidal anti-inflammatory drug with a synthetic glyceride ester: a preliminary attempt at a CNS drug delivery system for the therapy of Alzheimer's disease," Journal of Drug Targeting, vol. 8, no. 6, pp. 371-381, 2000.

[16] B. P. Imbimbo, "Why did tarenflurbil fail in Alzheimer's disease?" Journal of Alzheimer's Disease, vol. 17, no. 4, pp. 757-760, 2009.

[17] D. Zheng, X. Shuai, Y. Li et al., "Novel flurbiprofen derivatives with improved brain delivery: synthesis, in vitro and in vivo evaluations," Drug Delivery, vol. 23, no. 7, pp. 2183-2192, 2014.

[18] J. M. R. Parepally, H. Mandula, and Q. R. Smith, "Brain uptake of nonsteroidal anti-inflammatory drugs: ibuprofen, flurbiprofen, and indomethacin," Pharmaceutical Research, vol. 23, no. 5, pp. 873-881, 2006

[19] S. Lehrer, "Nasal NSAIDs for Alzheimer's disease," American Journal of Alzheimer's Disease \& Other Dementias, vol. 29, no. 5, pp. 401-403, 2014.

[20] S. C. Ghosh, B. Kim, J. Im et al., "Mitochondrial affinity of guanidine-rich molecular transporters built on m $\gamma$ o- and sc $\gamma$ llo-inositol scaffolds: stereochemistry dependency," Bulletin of the Korean Chemical Society, vol. 31, no. 12, pp. 3623-3631, 2010.

[21] J. Im, S. Kim, Y.-H. Jeong et al., "Preparation and evaluation of BBB-permeable trehalose derivatives as potential therapeutic agents for Huntington's disease," Medicinal Chemistry Communications, vol. 4, no. 2, pp. 310-316, 2013.

[22] K. K. Maiti, W. S. Lee, T. Takeuchi et al., "Guanidine-containing molecular transporters: sorbitol-based transporters show high intracellular selectivity toward mitochondria," Angewandte Chemie-International Edition, vol. 46, no. 31, pp. 5880-5884, 2007. 
[23] J. Im, K. K. Maiti, W. Kim, K.-T. Kim, and S.-K. Chung, "Cellular uptake properties of the complex derived from quantum dots and G8 molecular transporter," Bulletin of the Korean Chemical Society, vol. 32, no. 4, pp. 1282-1292, 2011.

[24] J. Im, W. Kim, K.-T. Kim, and S.-K. Chung, "Preparation of a $3^{\prime}$-azido-3' -deoxythymidine (AZT) derivative, which is bloodbrain barrier permeable," Chemical Communications, no. 31, pp. 4669-4671, 2009.

[25] J. Im, G. Biswas, W. Kim, K.-T. Kim, and S.-K. Chung, "A bloodbrain barrier permeable derivative of 5-fluorouracil: preparation, intracellular localization, and mouse tissue distribution," Bulletin of the Korean Chemical Society, vol. 32, no. 3, pp. 873879, 2011.

[26] S. Bhuniya, Y. J. Seo, and B. H. Kim, “(S)-(+)-Ibuprofen-based hydrogelators: an approach toward anti-inflammatory drug delivery," Tetrahedron Letters, vol. 47, no. 40, pp. 7153-7156, 2006.

[27] A. K. Pathak, V. Pathak, L. E. Seitz, K. N. Tiwari, M. S. Akhtar, and R. C. Reynolds, "A facile method for deprotection of trityl ethers using column chromatography," Tetrahedron Letters, vol. 42, no. 44, pp. 7755-7757, 2001.

[28] P. A. Wender, W. C. Galliher, E. A. Goun, L. R. Jones, and T. H. Pillow, "The design of guanidinium-rich transporters and their internalization mechanisms," Advanced Drug Delivery Reviews, vol. 60, no. 4-5, pp. 452-472, 2008.

[29] J. B. Rothbard, T. C. Jessop, and P. A. Wender, "Adaptive translocation: the role of hydrogen bonding and membrane potential in the uptake of guanidinium-rich transporters into cells," Advanced Drug Delivery Reviews, vol. 57, no. 4, pp. 495504, 2005.

[30] E. Wexselblatt, J. D. Esko, and Y. Tor, "On guanidinium and cellular uptake," The Journal of Organic Chemistry, vol. 79, no. 15, pp. 6766-6774, 2014. 

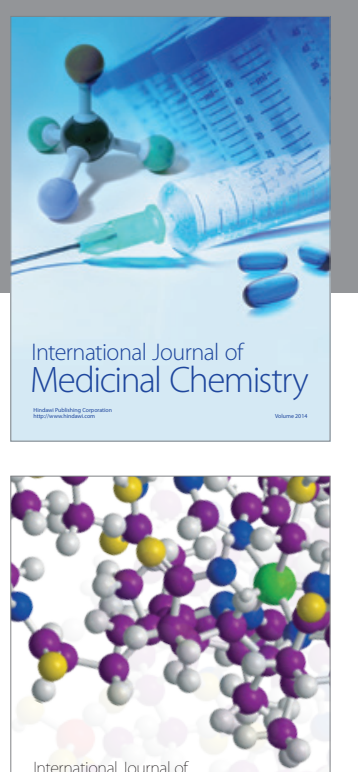

Carbohydrate Chemistry

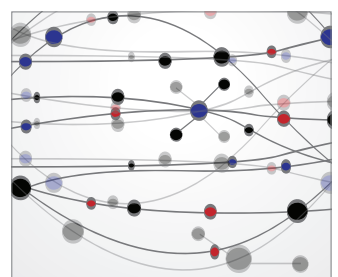

The Scientific World Journal
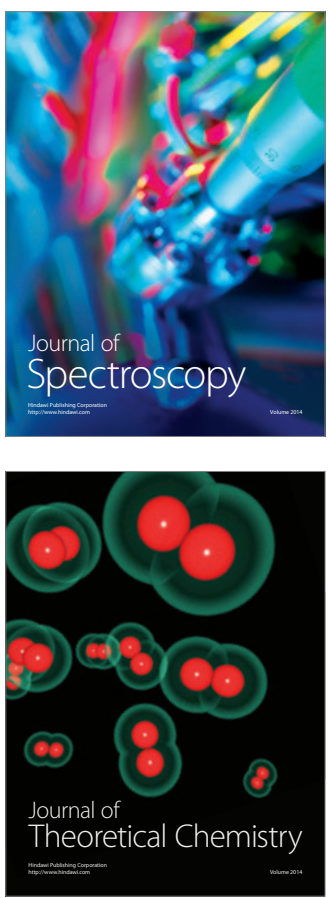
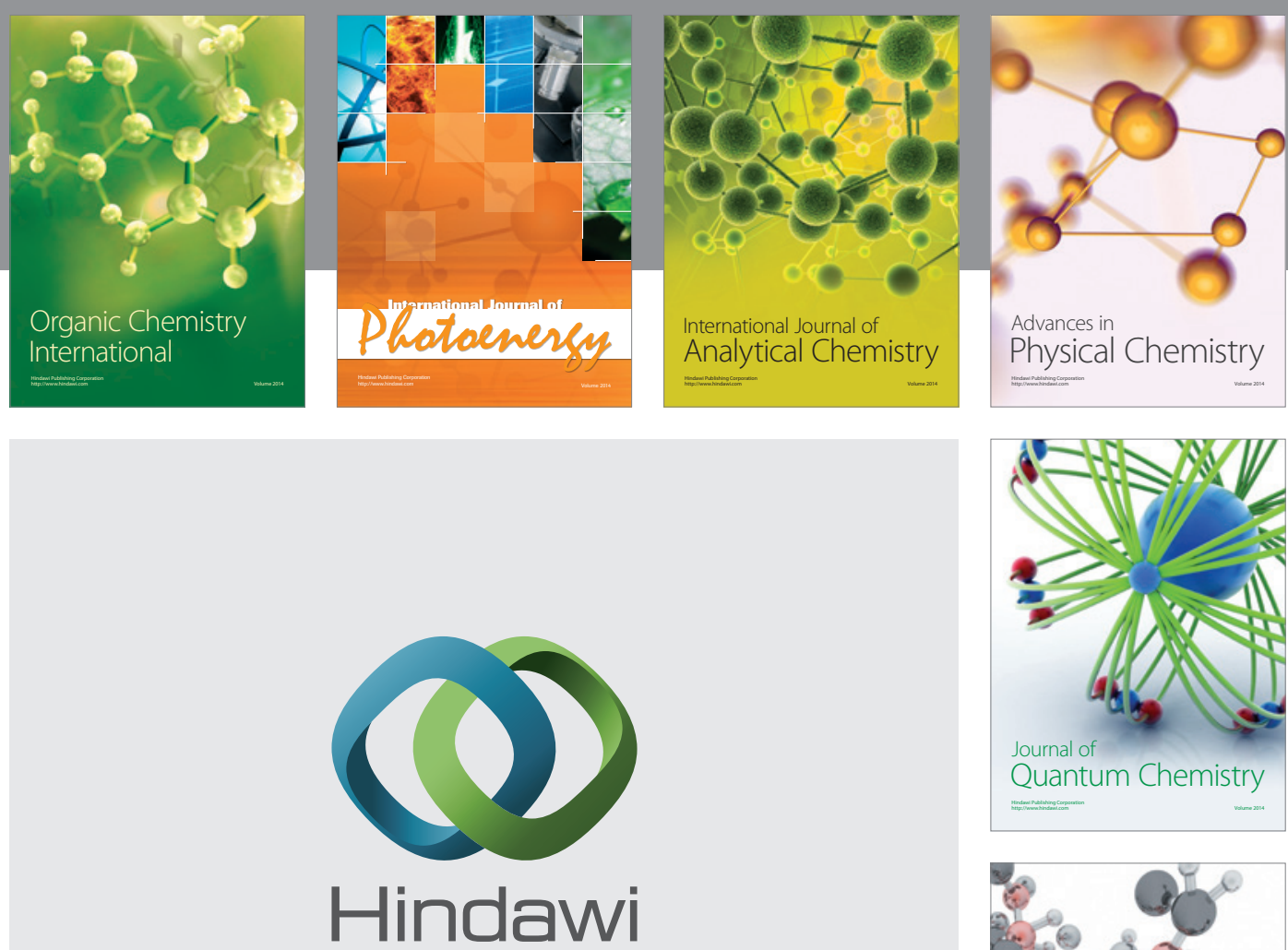

Submit your manuscripts at

https://www.hindawi.com

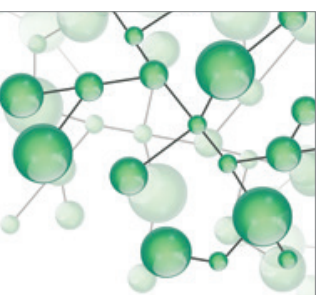

International Journal of

Inorganic Chemistry
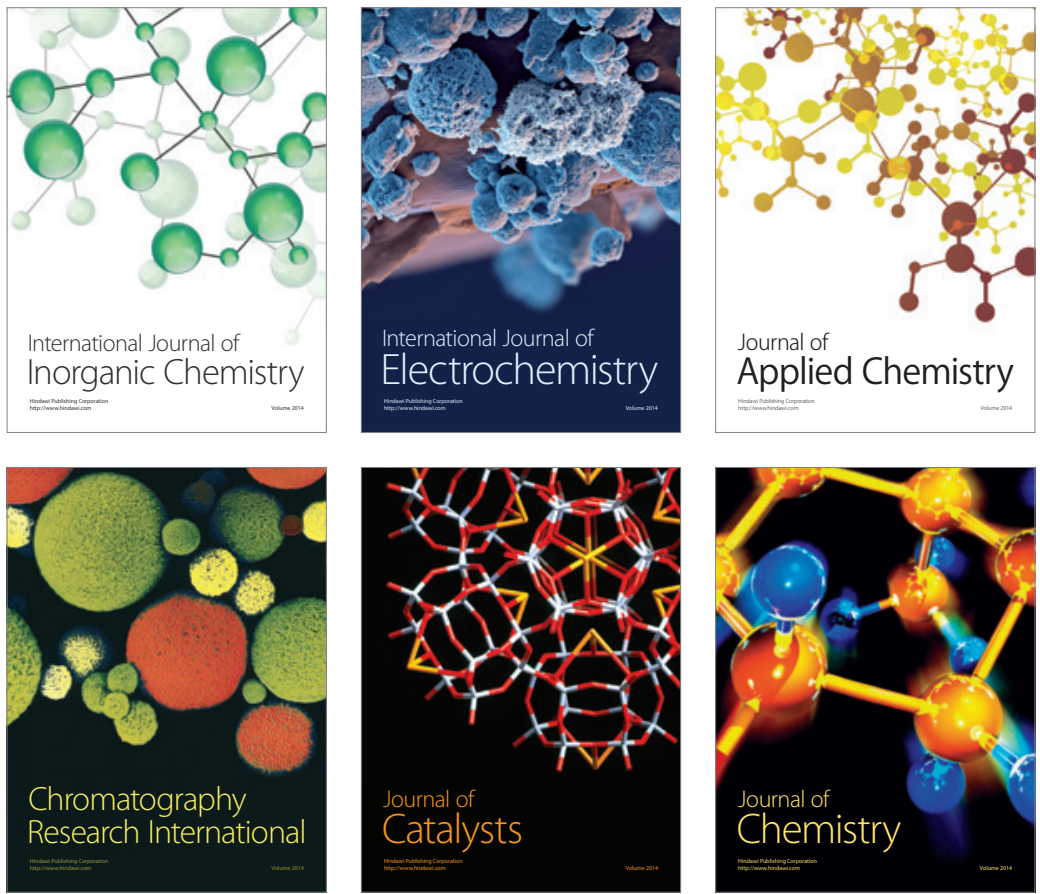

Journal of

Applied Chemistry
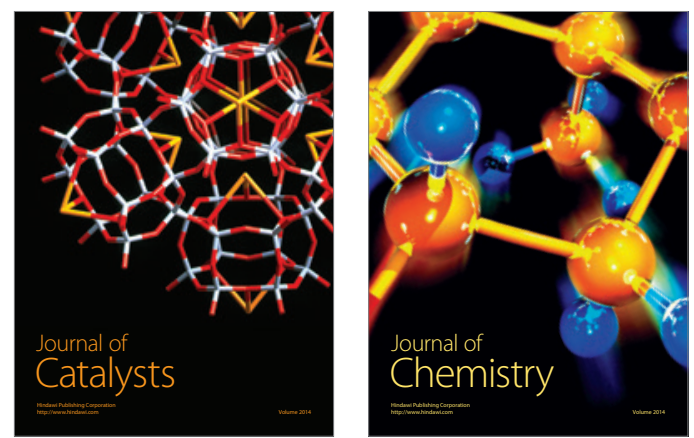
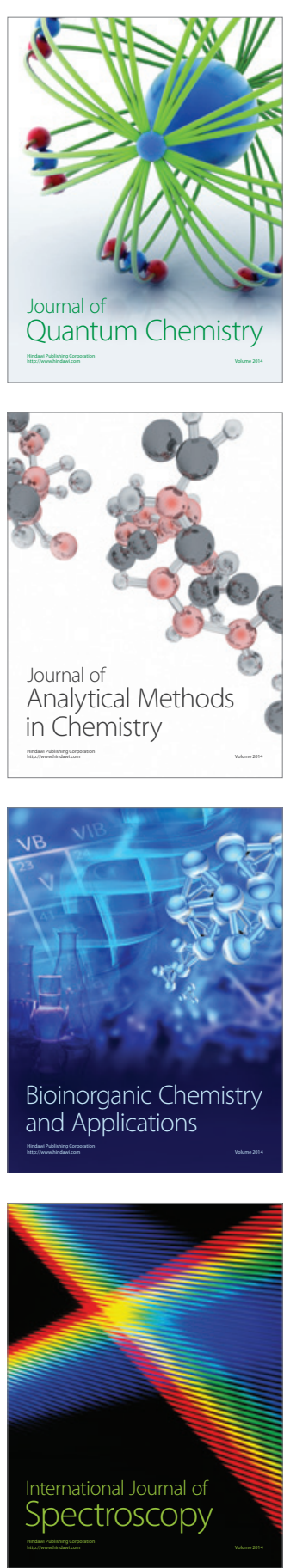